\title{
Impact of Teaching English Literature on the Improvement of EFL Learner's Performance in English Language
}

\author{
Sa'eed Sulieman Sorage Sa'eed \\ English Department, Faculty of Arts, Red Sea University, Port Sudan, Sudan \\ Email: saeed.oba20@gmail.com
}

How to cite this paper: Sa'eed, S. S. S. (2021). Impact of Teaching English Literature on the Improvement of EFL Learner's Performance in English Language. Open Journal of Modern Linguistics, 11, 647-654.

https://doi.org/10.4236/ojml.2021.114050

Received: April 14, 2021

Accepted: August 17, 2021

Published: August 20, 2021

Copyright (๑) 2021 by author(s) and Scientific Research Publishing Inc. This work is licensed under the Creative Commons Attribution International License (CC BY 4.0).

http://creativecommons.org/licenses/by/4.0/

\section{(c) (i) Open Access}

\begin{abstract}
The study aimed to investigate the impact of teaching English literature for EFL learners on the improvement and development of their performance in English language. The study carried out at Red Sea University, faculty of Arts and Humanities. The sample consisted of 10 EFL teachers and 30 students who are majoring in English. The researcher adopted descriptive analytical method for conducting the study. Two questionnaires were designed; one was responded by EFL teachers and the second one responded by EFL learners. The data of the study were presented by using percentage and mean. The study finds out that teaching English literature to large extent improves the performance of EFL learners in English language. The researcher recommends that, teachers should develop effective methods and strategies for teaching English literature for EFL learners to enhance their performance in English.
\end{abstract}

\section{Keywords}

Performance, Improvement, English Literature, Impact, Enhance, Strategies Majoring

\section{Introduction}

Teaching English literature has become important and inevitable particularly in foreign language departments all over the world. Almost all faculties of Arts curriculum include English literature course in which students expose to different genres of English literature. Hence students have chance to experience English literature at university. General speaking, literature plays a vital role in enhancing learner's ability in language skills. Carter and Long (1991) proves that literature can be employed in the curriculum to enhance the efficiency of language. 
Therefore, in many countries teaching English literature begins from the early stage of education at secondary levels and even in other countries from basic level. This shows the importance of literature in foreign countries. This point was supported by Zhen (2012: p. 35) who stated that, in many countries today English literature is a compulsory subject and indispensible subject and important elements in school curricula. It is an undeniable fact that English literature plays an important role in English teaching and learning in countries where English is foreign language. It is also worth noting that some colleges teach English literature course for the purpose of familiarizing students with native culture and entertainment but not for linguistic purpose. Li (2011: p. 241) mentions that in Chinese college, English literature is a compulsory and key for English majors. It is designed not only to help students learn the history of English literature and appreciate its literary works, but also to serve as cultivation of cultural awareness. Moreover, Tudor (1996) states that a good pedagogic approach for teaching literature should aim to elicit students response to the text and guiding them to a personal discovery, thus bringing in them the love, entertainment, enjoyment and appreciation of literary text.

\subsection{Statement of the Problem}

Based on the researcher's experience, he has noticed that EFL students who exposed to English literature perform better than other students who did not expose to English literature. This study is an attempt to investigate the impact of teaching English literature on the improvement of EFL learner's performance in English language.

\subsection{Objectives of the Study}

This study aims to:

Show the important of teaching English literature on raising and improving EFL learner's performance in English language.

\subsection{Questions of the Study}

1) To what extent does teaching English literature enhance learner's ability and performance in English?

2) How can teachers and instructors exploit teaching English literature to improve learner's performance in English?

\subsection{Hypotheses of the Study}

1) To large extent teaching English literature raises, enhances and improves learner's ability and performance in English language.

2) Teachers and instructors can use effective teaching methods and materials for teaching English literature.

\subsection{Significance of the Study}

The researcher hopes that this study will be of great benefit to EFL University 
learners; it may also help to make both teachers and learners aware of the importance of English literature in improving EFL learner's language performance. It is also hoped that the findings and results of the study will be of great value to syllabus designers and add to the field of applied linguistics and literature.

\subsection{Methodology of the Study}

The researcher employed descriptive analytical method for conducting the study. The data collected through two questionnaires which responded by teachers and EFL learners. The sample of the study consisted of 10 teachers and 30 students who are majoring in English. The data was analyzed by SPSS programme using mean, and percentage.

\subsection{Limitation of the Study}

The topic of the study is limited to investigate the impact of teaching English literature on the improvement of EFL learner's performance in English. The study carried out at Red Sea University, faculty of Arts and humanities. The sample of study consisted of 10 teachers and 30 EFL learners.

\section{Literature Review}

\subsection{The Reasons Why EFL Students Should Study English Literature}

English literature, particularly for EFL learners should be taught and introduced because it introduces students to some language aspects such as vocabulary items, culture and different language styles. It also familiarizes students with the concept of how to appreciate English discourse. The study of English literature can help to improve writing and language usage. Reading and studying English literature improves the ability to use and write sophisticated English. It improves the ability to read English with good understanding of different texts. Through reading English literature students can gain insights and develop a sense of thinking critically. Hill (1986: p. 12) points out that the study of English literature for EFL learners is necessary because it provides an opportunity to internalize language in terms of grammatical rules, phrases and vocabulary already learnt can be reinforced and at the same time new words and structure are achieved whereas Lazar (1993: p. 17) proves that literature enriches language in put in English class room and stimulate learning by providing meaningful and memorable contexts for processing and interpreting new language. Widdowson (1986: p. 33) states that, teachers use literature in teaching English so that they can broaden student's knowledge as well as improving language and cultural awareness.

\subsection{Importance of Teaching Literature for EFL Learners}

Teaching literature in foreign language situation greatly is important, because it helps learners to improve other language skills. As for native speakers, it is useful for them to come across to different style and authors and this does not mean 
that literature in native situation has nothing to do with the linguistic development. Native students particularly who interested in literature may benefit from studying literature for writing in the future. Sanju shows that literature plays a vital role in teaching the four language skills of reading, writing, listening and speaking. He adds that when using literature in the language class room, skills should be taught not in isolation but rather integrative. Teachers should try to teach basic language skills as integral part of oral and written language. Literature can be used as a means of creating both referential and interactional meaning, not merely as an aspect of the oral and written production of words, phrases and sentences. Literature enriches learner's vocabulary and language input. Zhen (2012: p. 37) mentions that literature is the key in teaching foreign language. Reading and studying literature involves language learning. Literature is essential part of EFL curriculum and syllabus because it expands learner's knowledge about the language. Learning literature helps students to learn different forms of language. The study of literature facilitates language learning, it has the power to create different opinions among learners in the class room. Literature teaching provides plenty of linguistic materials which can be exploited for enhancing the level of students in the language. It also enables learners to know much about native culture and humanity. Based on what mention above, currently teaching literature has been popular and inevitable in English language teaching situation. Akyel and Yaclin (1990: p. 175) show that in teaching literature teachers should aims to broaden students' knowledge improve cultural awareness, to simulative creativity; develop their appreciation of literature and to introduce students to an educative experience. Thus it is recommended for all teachers who teach literature to take and exploit the advantages of literature. In addition to, they should use method that foster and enhance learner's ability in English language.

\section{Method}

To conduct this study, the researcher used analytical descriptive method in which the results of two questionnaires were analyzed and described in terms of presenting it in a table showing percentage based on the respondents of the two questionnaires.

\subsection{Participants}

This study was carried at Red Sea University, faculty of Arts and humanities; hence the sample of study consisted of $30 \mathrm{EFL}$ students who are majoring in English and have studied English literature at the same University. They were chosen purposively by the researcher to collect valid, reliable and credible data. In addition10 EFL teachers who teach English literature.

\subsection{Instrument of Data Collection and Procedures}

The data of this study were collected from two questionnaires; the first was responded by 30 EFL students who are majoring in English and the second was 
responded by EFL teachers. The two questionnaires were consisted of ten statements in which respondents chose the option that suit their opinions and views. The statements of the two questionnaires were designed based on some assumptions of teaching English literature.

\section{Validity and Reliability of the Questionnaires}

To obtain the validity and reliability of the questionnaires, the researcher consults experts and teachers for making any modifications. Their comments were taken into consideration and the researcher made all necessary modifications. The researcher calculated the reliability coefficient measurement for the questionnaires using (split-half) method, dividing the answers into two parts, even numbers (2$4-6 \ldots$ ) and odd numbers (1-3-5...). The Pearson correlation coefficient between the two numbers was calculated. Then the reliability was calculated according to Spearman-Brown as follows:

Reliabilitycoefficient $=$

$\mathbf{R}=$ Pearson correlation coefficient

The statistical reliability and validity of the two questionnaires

\begin{tabular}{ccc}
\hline Questionnaire & Reliability & Validity \\
\hline Teacher & 0.82 & 0.91 \\
Student & 0.75 & 0.83 \\
\hline
\end{tabular}

As indicated in the above table, the reliability and validity coefficients of both teacher and student questionnaire are greater than (50\%). This shows the high validity and reliability of the questionnaires. Therefore, it is considered that the two questionnaires are valid and reliable.

\section{Data Analysis, Discussions and Results}

The data which were obtained from the two questionnaires will be analyzed and discussed as follow (Table 1).

From the following table it is shown that the percentage of respondents concerning statements $(1=73.3 \%, 2=90 \%, 4=73.3 \%$ and $7=73.3 \%)$ were more than $(50 \%)$ this indicate that English literature plays a vital role in improving and enhancing learner's performance in English. It is also indicated that EFL students benefit from the instructions of English literature because it improves their performance (90\%). It is also shown that the performance of EFL learners improve after studying English literature. Moreover, English literature enriches EFL learner's vocabulary items.

Following Table 2 indicates the responses and views of teachers who confirm the impact and important of teaching English literature for improving EFL learner's performance. As well as enriching learner's vocabulary items. This is obvious when noticing the results of respondents of the statements (1- 100\%, 3-100\%, 4$100 \%, 5-80 \%$ and 6- 100\%), which are greater percentages. 
Table 1. Analysis of student's questionnaire.

\begin{tabular}{|c|c|c|c|c|c|}
\hline No & Statements & Yes & Percentage & No & Percentage \\
\hline 1 & $\begin{array}{l}\text { English literature plays a vital role in } \\
\text { improving our performance. }\end{array}$ & 22 & $73.3 \%$ & 8 & $26.7 \%$ \\
\hline 2 & $\begin{array}{l}\text { I benefit from the instructions of } \\
\text { English literature to improve my } \\
\text { performance in English. }\end{array}$ & 27 & $90 \%$ & 3 & $10 \%$ \\
\hline 3 & $\begin{array}{l}\text { Before I studied English literature my } \\
\text { performance in English was poor. }\end{array}$ & 20 & $66.7 \%$ & 10 & $33.3 \%$ \\
\hline 4 & $\begin{array}{l}\text { My performance improved after I } \\
\text { studied English literature. }\end{array}$ & 22 & $73.3 \%$ & 8 & $26.7 \%$ \\
\hline 5 & $\begin{array}{l}\text { English literature did not improve } \\
\text { my performance in English. }\end{array}$ & 10 & $33.3 \%$ & 20 & $66.7 \%$ \\
\hline 6 & $\begin{array}{l}\text { I find difficulties and complexities in } \\
\text { understanding English literature. }\end{array}$ & 17 & $56.7 \%$ & 13 & $43.3 \%$ \\
\hline 7 & $\begin{array}{l}\text { English literature enriched } \\
\text { my vocabulary items. }\end{array}$ & 20 & $73.3 \%$ & 10 & $26.7 \%$ \\
\hline 8 & $\begin{array}{l}\text { English literature expanded my } \\
\text { knowledge in English culture. }\end{array}$ & 10 & $26.7 \%$ & 20 & $73.3 \%$ \\
\hline 9 & $\begin{array}{l}\text { Teachers encourage us to read } \\
\text { more about English literature } \\
\text { to improve our English. }\end{array}$ & 17 & $56.7 \%$ & 13 & $43.3 \%$ \\
\hline 10 & $\begin{array}{l}\text { Teachers engage us in an intensive } \\
\text { reading and tasks in English } \\
\text { literature for the purpose of } \\
\text { improving our English. }\end{array}$ & 19 & $63.3 \%$ & 11 & $36.7 \%$ \\
\hline
\end{tabular}

\section{Findings and Results}

After analyzing the responses of the two questionnaires, the researcher reached to some findings and results. They are shown in the following:

1) Teaching English literature to large extent improves the performance of EFL learners in English. This was confirmed by the respondents (teachers 100\%) which means; all of the respondents agreed with the point whereas student's responses reached $(73.3 \%)$ indicating that more than $50 \%$ agreed with the statement. (Table 1 and Table 2)

2) It is found out through reading English literature students enrich a quire new vocabulary. This point was supported by the percentage of both respondents; students (73.3\%) and teachers (100\%). (Table 1 and Table 2)

3) The results confirmed that students who studied English literature perform better than those who did not study or read English literature. This point was proved by the percentage of both respondents; students (73.3\%) and (100\%) of teacher's responses. 
Table 2. Analysis of teacher's questionnaire.

\begin{tabular}{|c|c|c|c|c|c|}
\hline No & Statements & Agree & Percentage & Disagree & Percentage \\
\hline 1 & $\begin{array}{l}\text { English literature enhances } \\
\text { and improves EFL learner's } \\
\text { performance in English. }\end{array}$ & 10 & $100 \%$ & - & - \\
\hline 2 & $\begin{array}{l}\text { Most of EFL teachers are } \\
\text { aware of the impact of } \\
\text { teaching English literature } \\
\text { on the improvement of } \\
\text { learner's performance. }\end{array}$ & 7 & $70 \%$ & 3 & $30 \%$ \\
\hline 3 & $\begin{array}{l}\text { EFL students always take the } \\
\text { merits of teaching English } \\
\text { literature because it improves } \\
\text { their performance. }\end{array}$ & 10 & $100 \%$ & - & - \\
\hline 4 & $\begin{array}{l}\text { EFL learners develop and } \\
\text { improve their performance } \\
\text { after exposing to } \\
\text { English literature. }\end{array}$ & 10 & $100 \%$ & - & - \\
\hline 5 & $\begin{array}{l}\text { Teaching methods and } \\
\text { materials in teaching English } \\
\text { literature should be effective } \\
\text { to improve learner's } \\
\text { performance. }\end{array}$ & 8 & $80 \%$ & 2 & $20 \%$ \\
\hline 6 & $\begin{array}{l}\text { Teaching English literature } \\
\text { enriches learner's } \\
\text { vocabulary items. }\end{array}$ & 10 & $100 \%$ & - & - \\
\hline 7 & $\begin{array}{l}\text { Teaching English literature } \\
\text { familiarizes learners with } \\
\text { different language styles. }\end{array}$ & 7 & $70 \%$ & 3 & $30 \%$ \\
\hline 8 & $\begin{array}{l}\text { Students who expose to } \\
\text { study English literature } \\
\text { perform better than students } \\
\text { who do not expose. }\end{array}$ & 10 & $100 \%$ & - & - \\
\hline 9 & $\begin{array}{l}\text { Teachers should encourage } \\
\text { students to read as much as } \\
\text { possible English literature to } \\
\text { improve their performance. }\end{array}$ & 7 & $70 \%$ & 3 & $30 \%$ \\
\hline 10 & $\begin{array}{l}\text { English literature is complex } \\
\text { and difficult for learners this } \\
\text { why it does not improve their } \\
\text { performance. }\end{array}$ & 4 & $40 \%$ & 6 & $60 \%$ \\
\hline
\end{tabular}

\section{Recommendations}

Based on the above mentioned findings and results, the researcher intends to recommend the following:

Teachers should encourage students to read more about English literature to improve their performance in English.

Teachers should engage students in an intensive task in English literature for the purpose of improving their performance in English. 
Teachers should develop effective methods and strategies for teaching English literature in a way that enhance, support and improve learner's performance in English.

\section{Conflicts of Interest}

The author declares no conflicts of interest regarding the publication of this paper.

\section{References}

Akyel, A., \& Yaclin, E (1990). Literature in the EFL Class: A Study of Goal-Achievement Incongruence. ELT Journal, 44, 174-180. https://doi.org/10.1093/elt/44.3.174

Carter, R., Long, M. N. (1991). Teaching Literature. Longman. https://www.worldcat.org/title/teaching-literature/oclc/22108765

Hill, J. (1986). Teaching Literature in the Language Class Room. Macmillan.

Lazar, G. (1993). Literature and Language Teaching: A Guide for Teachers and Trainers. Cambridge University Press. https://doi.org/10.1017/CBO9780511733048

Li, D. (2011). How to Teach and Learn English Literature in Electronic Era. International Journal of Electronic Education, 1, No. 3, 241-245.

http://www.ijeeee.org/index.php? $m=$ content $\& c=i n d e x \& a=$ show\&catid=24\&id=296

Tudor, I. (1996). Learner-Centredness as Language Education. Cambridge University Press.

Widdowson, H. (1986). Teaching Language Communication. Oxford University Press.

Zhen, C. (2012). Characteristics and Strategies of Literature Teaching in the EFL Context in China. International Journal of Electronics and Communication, 5, No. 3, 35-43. https://www.ripublication.com/ijepa/ijepav2n1 3.pdf 